\title{
PLANT DIVERSITY ASSOCIATED WITH PRODUCTIVE BRAZIL NUT TREES IN THE LEADING PRODUCING REGIONS IN THE AMAZONAS
}

\author{
Nadiele Pereira Pacheco ${ }^{1}$, Kátia Emídio da Silva² ${ }^{2}$ Nabor da Silveira Pio $^{3}$, Francisca Dionizia de Almeida \\ Matos $^{4}$, Rosiele Santos Vasconcelos ${ }^{5}$ \\ ${ }^{1}$ Instituto de Desenvolvimento Agropecuário e Florestal Sustentável do Estado do Amazonas, Departamento de Assistência Técnica e \\ Extensão Florestal, Manaus, AM, Brazil - *nadielep@gmail.com \\ 2 Empresa Brasileira de Pesquisa Agropecuária - Amazônia Ocidental, Manaus, AM, Brazil - katia.emidio@embrapa.br \\ ${ }^{3}$ Universidade Federal do Amazonas, Programa de Pós-Graduação em Ciências Florestais e Ambientais, Manaus, AM, Brazil - \\ nspio.ufam@gmail.com \\ ${ }^{4}$ Instituto Nacional de Pesquisas da Amazônia, Coordenação de Pesquisas em Botânica, Manaus, AM, Brazil - fmatos@inpa.gpv.br \\ ${ }^{5}$ Secretaria Municipal do Meio Ambiente, Autazes, AM, Brazil - rosi.engflorestal@ hotmail.com
}

Received for publication: 02/06/2020 - Accepted for publication: 07/04/2021

\begin{abstract}
Resumo
Diversidade vegetal associada a castanheiras produtivas, nas principais regiões produtoras do Amazonas. Bertholletia excelsa, conhecida como castanheira, é uma espécie que produz um fruto coletado por populações tradicionais que comercializam suas amêndoas, como alternativa na composição da renda familiar. Avaliou-se a diversidade vegetal associada à castanheiras produtivas, por meio da comparação das diferenças florísticas entre e dentro de seis castanhais. A pesquisa foi conduzida nas principais regiões produtoras: (1) Reserva de Desenvolvimento Sustentável Piagaçu Purus/Anori, (2) Propriedade do Jutica /Tefé, (3) Comunidade Jatuarana/Manicoré, (4) Sítio Gostoso/Amaturá, (5) Comunidade Mufuá/Lábrea, e (6) Reserva Extrativista do Rio Unini/Barcelos. As diferenças florísticas foram analisadas por meio do Escalonamento Multidimensional Não Métrico - nMDS, com validação do arranjo estrutural das parcelas, por meio da análise de variância multivariada (Permanova-Adonis a $5 \%$ de probabilidade). Todos os indivíduos com DAP $\geq 10 \mathrm{~cm}$, vizinhos às castanheiras, foram identificados em 15 parcelas circulares de 15 metros de raio em cada castanhal. As parcelas foram instaladas ao redor de castanheiras selecionadas a partir da classe de produção de frutos ( 5 de alta, 5 de média e 5 de baixa produtividade). Foram registrados 3.039 indivíduos, Jatuarana com maior número de indivíduos (577). Os ambientes florestais apresentaram grande diversidade florística, índice de ShannonWeaver entre de 3,65 a 4,19; porém, estes valores não foram estatisticamente significativos (Kruskal Wallis) entre as localidades. No contexto das classes de produção não se observou um padrão de agrupamento das parcelas de mesma classe. Observou-se diferenças florísticas significativas entre as seis localidades, segundo permanova/adonis p-valor $=0,001$.
\end{abstract}

Palavras-chave: Castanha-do-brasil, composição florística, dissimilaridade, Escalonamento Multidimensional Não Métrico - nMDS.

\begin{abstract}
Bertholletia excelsa, known as Brazil nut tree, is a species that produces a fruit collected by traditional populations that trade their almonds, as an alternative in the composition of the family income. The plant diversity associated with productive Brazil nut trees was evaluated by comparing the floristic differences between and within six Brazil nut tree plots. The experiment was conducted in the leading producing regions of Amazonas: (1) Piagaçu Purus/Anori Sustainable Development Reserve, (2) Jutica/Tefé Farm, (3) Jatuarana/Manicoré Community, (4) Gostoso/Amaturá Farm, (5) Mufuá/Lábrea Community, and, (6) Unini River/Barcelos Extractive Reserve. The floristic differences were analyzed using the Non-Metric Multidimensional Scaling - nMDS, with validation of the structural arrangement of the plots, through analysis of multivariate variance (Permanova-Adonis at $5 \%$ probability). All individuals with $\mathrm{DBH} \geq 10 \mathrm{~cm}$, neighbors to the selected Brazil nut trees, were identified in 15 circular plots of 15 meters radius in each Brazil nut tree. The plots were installed around Brazil nut trees selected based on their fruit production class ( 5 high, 5 medium, and 5 low productivity). It was registered 3,039 individuals in which Jatuarana showed the largest number of individuals (577). The forest environments showed great floristic diversity, Shannon-Weaver index between 3.65 and 4.19; however, these values were not statistically significant (Kruskal Wallis) among the sites. In the context of production classes, there was no pattern of clustering plots of the same class. Significant floristic differences were observed between the six locations, according to permanova / adonis p-value $=0.001$.

Keywords: Brazilian nuts, dissimilarity, floristic composition, Non-Metric Multidimensional Scaling - nMDS.
\end{abstract}

\section{INTRODUCTION}

Bertholletia excelsa Bonpl., popularly known as Brazil nut tree, is a forest species that produces a fruit that is collected by traditional populations that sell their almonds, Brazilian nuts, as an alternative in the composition of family income. However, there are few studies about the native Brazil nut trees in the Amazon and the plant diversity that compose them, especially about the vegetation directly associated with the Brazil nut trees, which certainly contribute to the formation of a habitat resulting from the interaction between its various 
components. This diversity, associated with other factors, may influence the fruit production of Brazil nut trees and the general structure of Brazil nut tree plots, whose maintenance can represent the sustainability of Brazil nut trees over time.

Amazonas has several Brazilian nut processing units which are distributed throughout all the producing regions in the state, spread over the interior cities and even in the capital city. These agribusinesses produce dried and vacuum-packed Brazilian nuts and trade their products to the regional, domestic, and international markets. This makes the demand for fresh almonds increasingly intense, therefore encouraging collection, which is mainly carried out by traditional populations (Brazil nut collectors) nowadays.

It has been known that the production of fruits and seeds varies between years in populations and between individuals in the same population and that fruit production in Brazil nut tree native to the Amazon is concentrated in a small number of individuals (TONINI, 2014). Scoles \& Gribel (2011) analyzed the structure and regeneration of Brazilian nut populations in places subject to extractive activities such as in the Lago do Capanã Grande Extractive Reserve (Madeira River, Amazonas, Brazil). They found that the number of juveniles and adult Brazil nut trees is five times higher in areas of intense use than in those that are moderately used, suggesting that extractive activities and disturbances in the understory caused by human presence may favor (intentionally or not) the regeneration of Brazil nut trees in most frequently used areas.

In the Amapa State, Paiva (2011) evaluated the population structure and the proportion of juveniles in the population of wild Brazil nut trees with a long history of extraction and intense collection pressure and found that the population structure showed individuals distributed in all classes of diameter and that intensive collection was not jeopardizing the population regeneration.

There is a complex network of biotic and abiotic interactions that may influence fruit production and the structure of Brazil nut populations. There is little knowledge available about the plant diversity associated with Brazil nut trees orchards in the Amazon, which makes it difficult, for example, to develop public policies for the species, concerning the management of Brazil nut trees, especially in aspects related to the maintenance of neighboring species and their possible interactions with Brazil nut trees, influencing fruit production, therefore requiring the adoption of strategies for the conservation of Brazil nut trees, aiming at their sustainability.

According to Magurran (1988), the organization of communities and their floristic affinities can be analyzed using parameters of diversity on a local and regional scale; it is no different with Brazil nut trees, it is essential to know the plant diversity associated with Brazil nut trees, selected according to productivity classes, whose evidence can be of great use in the management of Brazil nut trees orchards due to possible biological associations that can influence fruit production rates in the Brazil nut trees.

Therefore, this study aimed to evaluate the diversity associated with productive Brazil nut trees as a way to contribute to the expansion of knowledge about the diversity of vegetation associated with Brazil nut trees in Amazonas, to subsidize further management actions.

\section{MATERIALS AND METHODS}

This study was conducted in the leading producing regions of Brazil nuts in the Amazonas State: Piagaçu Purus Sustainable Development Reserve (Uixi) (Anori municipality), Jutica Farm (Tefé municipality), Jatuarana Community (Manicoré municipality), Gostoso Farm (municipality of Amaturá), Mufuá Community (municipality of Lábrea), Unini River Extractive Reserve (municipality of Barcelos) (Figure 1). Permanent plots were implemented under the MapCast project (Native Brazil nut trees mapping and Socioenvironmental and Economic Characterization of the Production Systems of Brazilian nuts in the Amazon), following the protocol for the installation and measurement of permanent plots (GUEDES et al., 2017). The plots have dimensions of $300 \mathrm{~m} \times$ $300 \mathrm{~m}$ (9 ha) (Figure 2). It is worth noting that all study areas (Brazil nut trees) are of primary use for collecting Brazil nut and have not been subjected to logging.

In each of these plots, an inventory was made of all Brazil nut trees with a diameter at breast height $\mathrm{DBH} \geq 10 \mathrm{~cm}$. Each tree (Brazil nut trees) was identified with an aluminum plate and the diameter measurement point (PMD) was marked with red ink. The identification followed the following pattern: ZZZ_WWW. [plot (3) _number (3)], where the number inside "( )", means the number of digits.

After the inventory of the permanent plots, the selection of focal Brasil nut trees was carried out according to their productivity, with five (05) individuals represented in each of the three classes of trees in reproductive phase: a) the most productive ( $\geq 200$ fruits), b) with intermediate production and (100-200 fruits) and c) do not produce or with very low production ( $<100$ fruits). Thus, for the study of the diversity associated with Brasil nut trees, a total of 15 trees were selected, of which five (05) in each production class, which were called focal Brasil nut trees. 
In relation to fruit counting, for this study, the counting performed by the Brazil nut collector during the harvest period was considered, since for safety reasons we did not perform data collections during the peak harvest period in the Brasil nut trees.

Around each of these focal Brasil nut trees, 15 circular plots were installed following the protocol for installing circular plots and characterizing the vegetation associated with tropical tree species (Silva et al., 2017). The selected focal individuals are separated at least $31 \mathrm{~m}$ from each other so that to avoid overlapping of the canopies. They represent the center of each circular plot, delimited with a radius of $15 \mathrm{~m}\left(\operatorname{area}=706.85 \mathrm{~m}^{2}\right)$, considering the center of the focal individual at the beginning of the radius of measurement. Each circular plot is composed of 08 subplots, represented by 08 arches of the same angle $\left(45^{\circ}\right)$, Figure 3 . The total area sampled in each Brazil nut tree was 1.06 ha, totaling 6.36 ha sampled in the six locations.

Then the inventory was carried out within each arch defined in the installation of the circular plot, identifying all neighboring individuals with $\mathrm{DBH} \geq 10 \mathrm{~cm}$. The floristic composition was analyzed based on the numbers of individuals, species, genera, and families. To estimate the floristic diversity in the six Brazil nut trees, the Shannon diversity index (H ') (SHANNON \& WEAVER, 1949) and the Equitability Index (J) were used, in which the variable used in the index estimates was the number of individuals of each species.

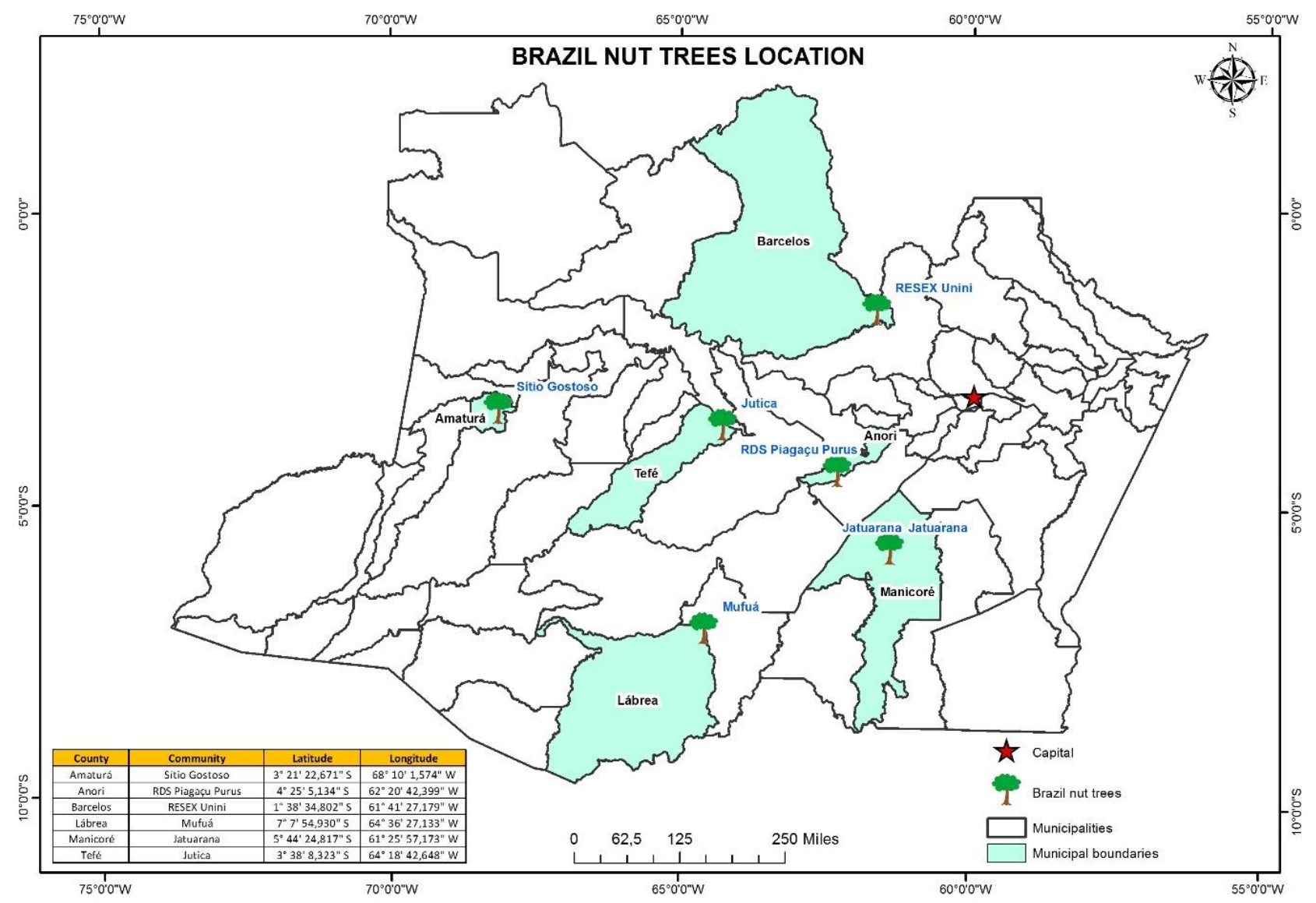

Figure 1. Map of study site localization (Brazil nut trees).

Figura 1. Mapa de localização das áreas de estudo (castanhais). 


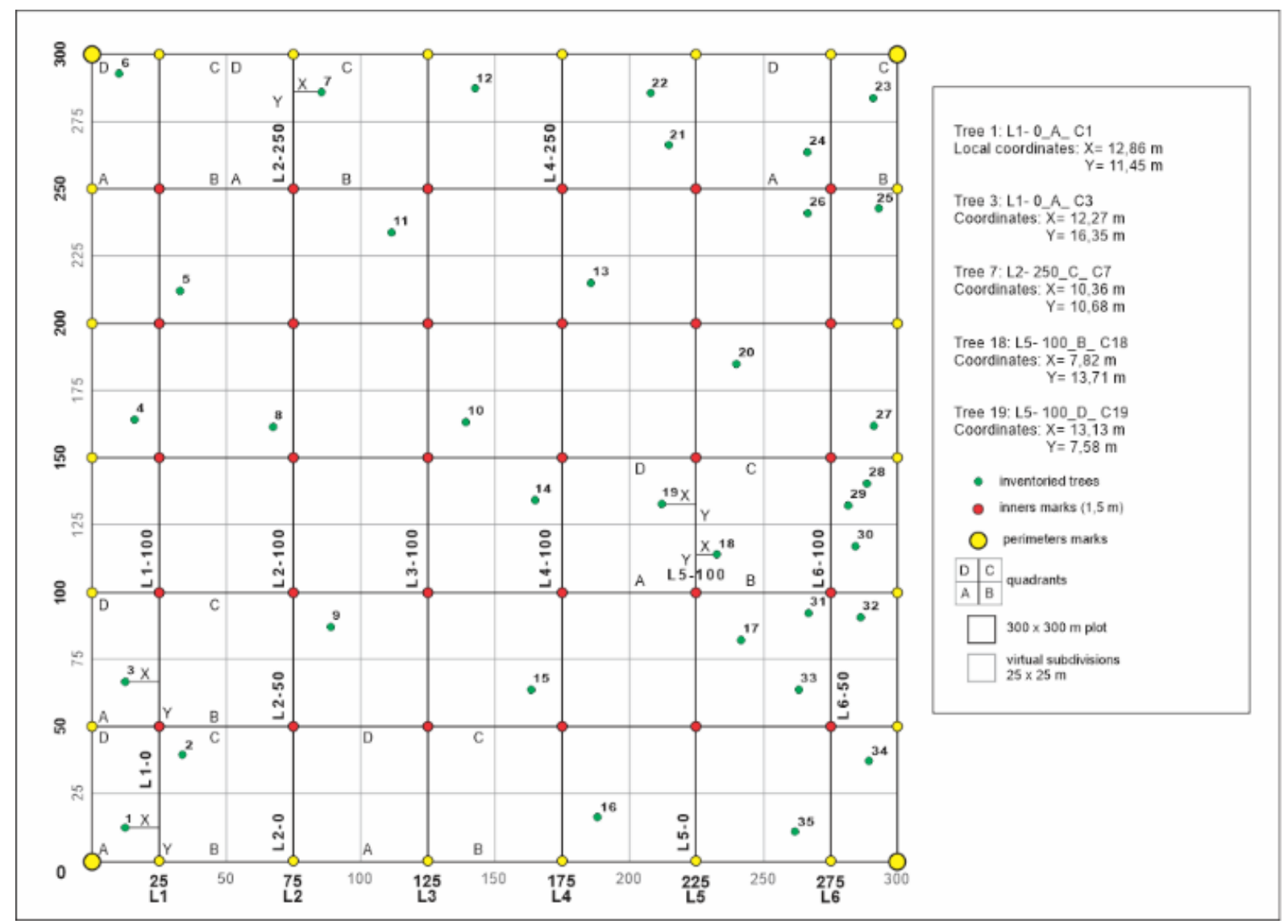

Figure 2. Schematic drawing of the permanent plot. L1 to L6 represent the lines. Source: Guedes et al. (2017). Figura 2. Desenho esquemático da parcela permanente. L1 a L6 representam as linhas. Fonte: Guedes et al. (2017).

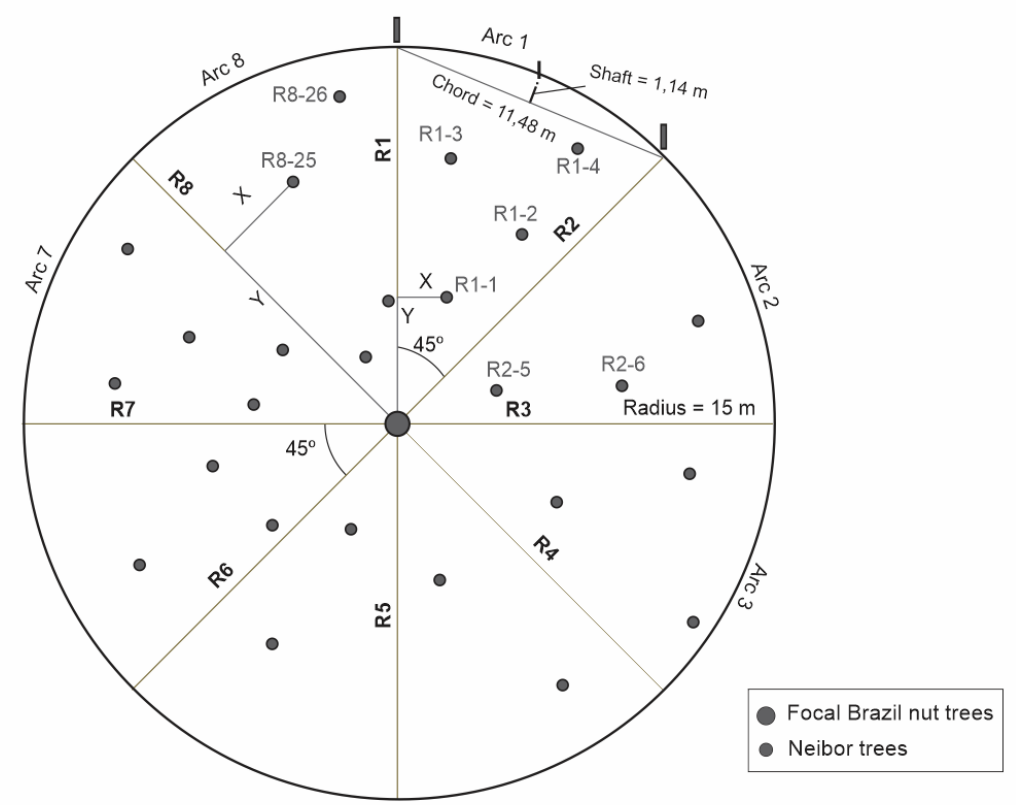

Figure 3. Circular plot. Source: Silva et al. (2017).

Figura 2. Parcela circular. Fonte: Silva et al. (2017).

The assessment of the data structure through the comparison of the floristic differences between the plots was performed employing the Non-Metric Multidimensional Scaling technique nMDS, using the Bray-Curtis 
index for the dissimilarities. As a way to statistically compare the floristic differences between the plots (beta diversity), as well as validating the nMDS results, a multivariate analysis of variance, based on permutation (Permanova-adonis) was performed. The test hypotheses were the following:

$\mathrm{H}_{0}$ : There is no significant difference in the floristic composition among plots;

$\mathrm{H}_{1}$ : There are significant differences in the floristic composition.

Regarding the cases in which $\mathrm{H}_{1}$ was true, therefore rejecting $\mathrm{H}_{0}$, a paired test was performed to identify the plots that are statistically different, using the "pairwiseadonis" function, from the Vegan package (R-Core Team, 2018).

After the execution of the forest inventory in the 15 circular plots (1.06 ha) in the six Brazil nut trees (6.36 ha), a total of 3,039 individuals with $\mathrm{DBH} \geq 10 \mathrm{~cm}$ were identified, distributed in 297 species, 144 genera, and 55 families.

The locality Jatuarana (Manicoré) had the largest number of individuals (577) represented in 133 species and Unini (Barcelos), showed the smallest number (369 individuals), registered in 80 species (Table 1), 43 of which are exclusive from Jatuarana and 18 exclusives from Unini.

\section{RESULTS}

In the six studied Brazil nut trees, a total of 3,039 individuals with $\mathrm{DBH} \geq 10 \mathrm{~cm}$ were identified, distributed in 297 species, 144 genera, and 55 families.

The locality Jatuarana (Manicoré) had the largest number of individuals (577) represented in 133 species and Unini (Barcelos), the smallest number (369 individuals), registered in 80 species (Table 1), 43 of which are exclusive from Jatuarana and 18 from Unini.

Concerning the species, the six localities (Brazil nut trees) presented a range of 80 to 133 species. The Brazil nut trees in Unini River showed small value of the richness and the Jatuarana, located in the municipality of Manicoré, the highest species richness in this study, as shown in Table 1.

Table 1. Comparison of the floristic composition among the assessed sites under study in the Amazonas. Tabela 1. Comparação da composição florística entre as localidades estudadas em estudo no Amazonas.

\begin{tabular}{|c|c|c|c|c|c|}
\hline Location & N. individuals & N. of families & N. genera & N. species & N. exclusive species \\
\hline Jatuarana & 577 & 36 & 84 & 133 & 43 \\
\hline Jutica & 553 & 35 & 75 & 121 & 38 \\
\hline Mufuá & 559 & 32 & 59 & 96 & 15 \\
\hline Sítio Gostoso & 497 & 33 & 66 & 86 & 8 \\
\hline Unini & 369 & 34 & 63 & 80 & 18 \\
\hline Uixi & 484 & 36 & 69 & 121 & 13 \\
\hline TOTAL & 3.039 & - & - & - & 118 \\
\hline
\end{tabular}

The families that had the largest number of individuals were the following: Sapotaceae, Fabaceae, Moraceae, Annonaceae, Arecaceae, Lecythidaceae, Myristicaceae, Lauraceae, Violaceae, and Burseracea, totaling $70.7 \%$ of all sampled individuals, and the remaining 45 families contributed only with $29.3 \%$ of individuals. The families Araliaceae, Bixaceae, Ebenaceae, Erythroxylaceae, Humiriaceae, Linaceae, Polygonaceae, Rhizophoraceae, and Solanaceae contributed with only one individual each.

The Fabaceae family had the largest number of individuals, totaling 377 occurring in all locations. By analyzing each Brazil nut tree, it was possible to found that the Fabaceae family occurred in all locations followed by the Moraceae and Annonaceae families that occurred in four locations. The Brazil nut trees in Jutica and Unini were the most different ones, showing only two families in common with the other Brazil nut trees: Fabaceae and Annonaceae.

The results of alpha diversity for the Shannon-Weaver Diversity Index $\left(\mathrm{H}^{\text {') }}\right.$ between the studied locations varied from 3.65 to 4.19 (Table 2). In order to test the significance of the Shannon indexes found in the experiment, the Kruskal-Wallis non-parametric test was applied, which evidenced that there were no statistical differences between the Brazil nut trees ( $\mathrm{p}$-value $=0.2$ ). 
Table 2. Diversity Index of Shannon Weaver for each Brazil nut trees.

Tabela 2. Índice de diversidade de Shannon Weaver para cada castanhal.

\begin{tabular}{cccc}
\hline Location & No $^{\circ}$ individuals & N. species & $\mathrm{H}^{\prime}$ \\
\hline Jatuarana & 577 & 133 & 4,15 \\
\hline Jutica & 553 & 121 & 4,19 \\
\hline Mufuá & 559 & 96 & 3,65 \\
\hline Gostoso & 497 & 86 & 3,77 \\
\hline Unini & 369 & 80 & 3,79 \\
\hline Uixi & 484 & 121 & 4,16 \\
\hline
\end{tabular}

Legend: H' is the Shannon Weaver index.

The floristic differences between and within the Brazil nut trees can be seen in Figure 4. It can be seen that there is a tendency for the parcels to be grouped in each location, which was confirmed by the Adonis test (permanova $\mathrm{p}$-value $=0.001$ ), that is, highly significant, evidencing significant differences in floristic compositions between the six plantations. When performing the paired comparison test between plots, all pairs of the comparisons were significant $(\mathrm{p}$-value $=0.015)$.

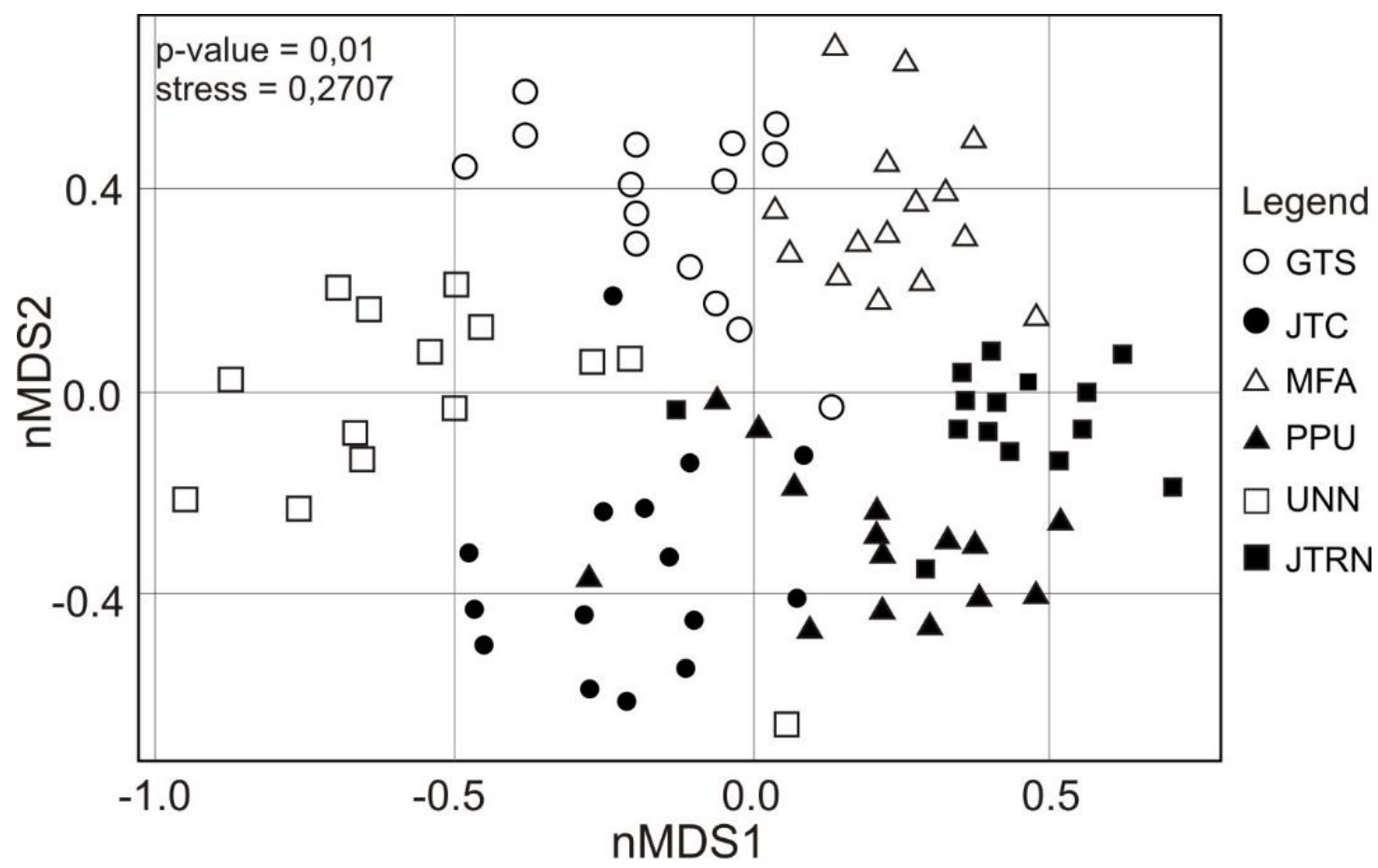

Figure 3. Comparison among the six sites, Amazonas. Non-metric Multidimensional Scaling - nMDS, where GTS= Gostoso Farm, JTC=Jutica, MFA=Mufuá, PPU= Uxi, UNN=Unini, JTRN=Jatuarana.

Figura 4. Comparação entre as seis localidades, Amazonas. Escalonamento Multidimensional Não Métrico nMDS, onde GTS=Sítio Gostoso, JTC=Jutica, MFA=Mufuá, PPU= Uxi, UNN=Unini, JTRN=Jatuarana.

It is observed in for all the six plantations that plots of different production classes are mixed together, therefore, there is no indication of significant differences in the floristic composition of the plots, in different lasses of production of Brazil nut s (Figures 5 and 6), in other words, there are no differences between the groups (high, medium and low). 

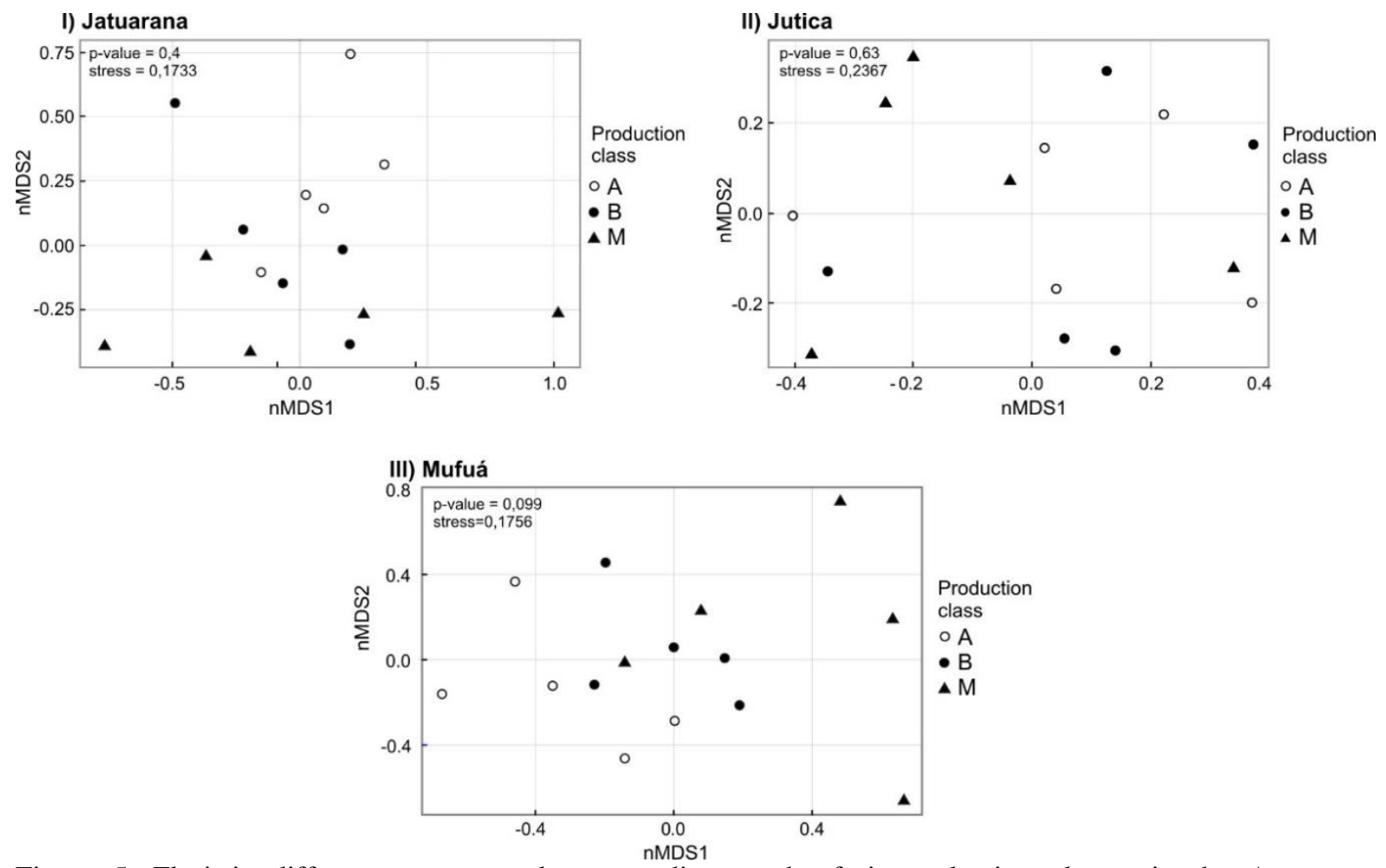

Figure 5. Floristic differences among plots according to the fruit production classes in the Amazonas. Escalonamento Multidimensional Não Métrico - NMDS, where $\mathrm{A}=$ high, $\mathrm{B}=$ low and $\mathrm{M}=$ average fruit production, and I=Jatuarana, II = Jutica, III=Mufuá.

Figura 6. Diferenças florísticas entre parcelas segundo classes de produção de frutos no Amazonas. Escalonamento Multidimensional Não Métrico - NMDS, onde $\mathrm{A}=$ alta, $\mathrm{B}=$ baixa e $\mathrm{M}=$ média produção de frutos $\mathrm{e}$ I=Jatuarana, II = Jutica, III=Mufuá.
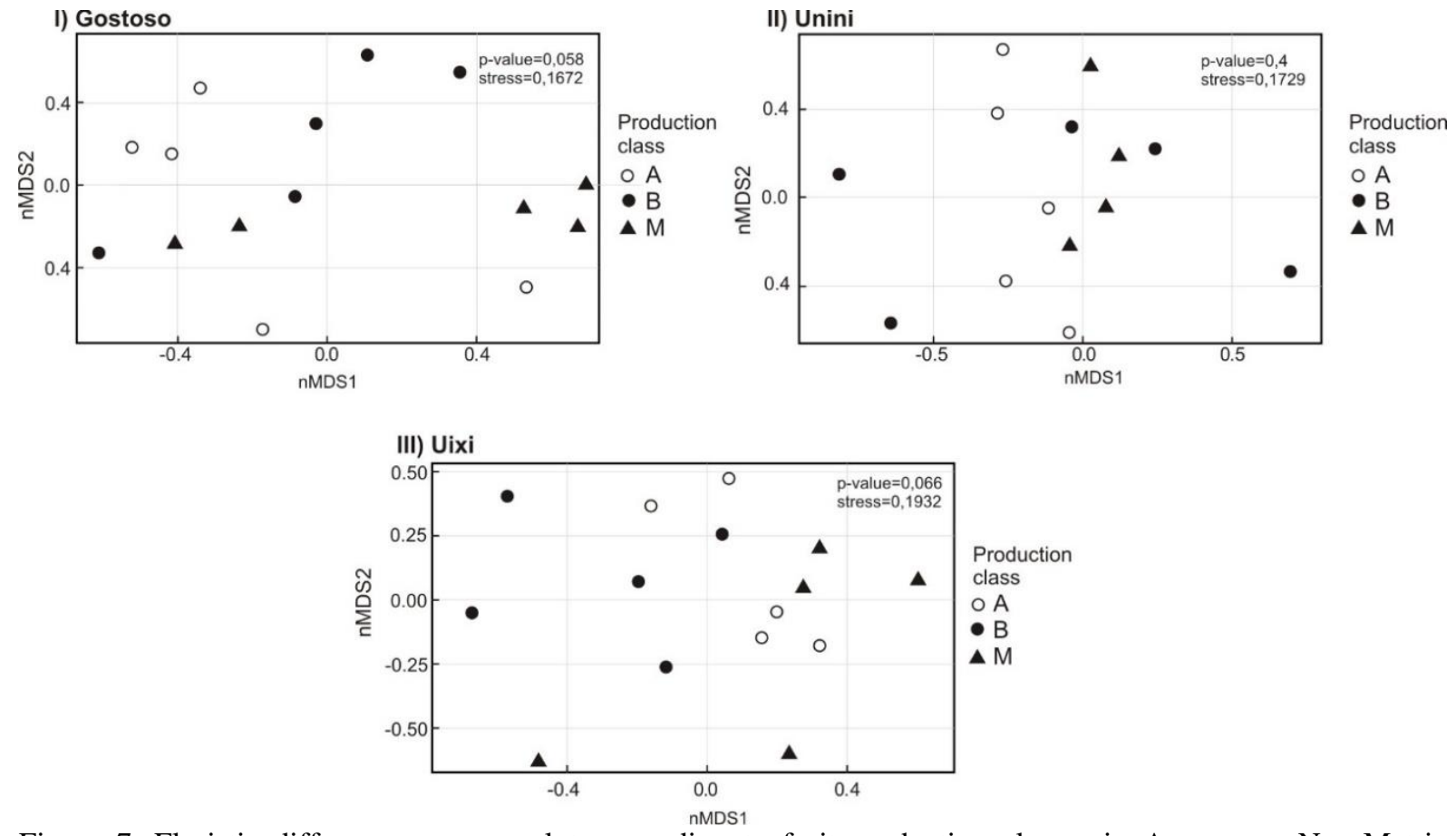

Figure 7. Floristic differences among plots according to fruit production classes in Amazonas. Non-Metric Multidimensional Scaling - NMDS, where $\mathrm{A}=$ high, $\mathrm{B}=$ low and $\mathrm{M}=$ average fruit production and $\mathrm{I}=$ Gostoso Farm, II = Unini, III = Uxi. 
Figura 8. Diferenças florísticas entre parcelas segundo classes de produção de frutos no Amazonas. Escalonamento Multidimensional Não Métrico - NMDS, onde A= alta, B= baixa e M = média produção de frutos e $\mathrm{I}=$ Sítio Gostoso, II = Unini, III=Uxi.

\section{DISCUSSION}

In comparison to other studies, it was found that Silva (2016) identified in 15 hectares, 8,771 individuals represented by 264 species in the experimental field of EMBRAPA - Manaus, Amazonas State. In another study, at Caracaraí, Roraima, Brazil, Condé \& Tonini (2013) identified 4,724 individuals, belonging to 165 species, in a total of 9 sampled hectares. We can associate the differences to the different sample sizes, differences in areas, differences in the successional stage of each area, variations in botanical identification, among others.

Silva (2011) approached the floristics and spatial structure in 15 hectares of permanent plots in the dense terra firma forest in the Central Amazon (Manaus -Amazonas) and found the families Fabaceaae-Mimosoideae, Fabaceae-Faboideae, and Fabaceae-Caesalpinoideae, respectively, in this order with the largest number of species. The Fabaceae family stood out in that study, similar to the one found in our current study and others carried out in the Amazon region (PEREIRA et al., 2011; CONDÉ; TONINI, 2013; DIONISIO et al., 2016; SANTOS et al., 2017).

According to Knight (1975), the Shannon-Weaver Index for tropical forests usually ranges from 3.83 to 5.85. The indices calculated between the locations of our study ranged from 3.65 to 4.19, therefore, within the patterns observed for tropical forests, indicating a high diversity and that Brazil nut trees are a way of maintaining the diversity of tropical forests.

Silva (2016) found high Shannon-Weaver indices of 4.49 in the experimental field of EMBRAPA (Manaus-AM). On the other hand, Condé \& Tonini (2013), when studying in the region of Caracaraí, state of Rondônia, a neighboring state, obtained Shannon-Weaver H'=3.27.

When the change in species composition was evaluated over the six studied environments, significant changes were observed among the six locations, as evidenced by the NMDs, and the subsequent tests. Such a result was expected as the permanent plots were installed in regions bathed by rivers of different structures, especially in water quality, wildlife, among other variables that may be contributing to the floristic composition of each plantation.

In a deeper analysis of the Brazil nut trees, searching for differences in the composition according to the fruit production classes, no differences were found among the groups. In other words, the floristic composition associated with the selected Brazil nut trees did not vary significantly when considering the association by classes of fruit production. More in-depth studies should be carried out to understand the relationships between species neighboring Brazil nut trees, concerning the attraction of Brazil nut trees pollinators or the creation and maintenance of habitats more favorable to fruit growth and production. No other studies related to this association were identified in the literature.

\section{CONCLUSIONS}

- The different Brazil nut trees producing regions in the Amazonas State differ from each other with the floristic composition and the diversity evaluated by the general Shannon index;

- The floristic differences observed between the vegetation associated with the Brazil nut trees, within each plantation are not significant enough to explain the pattern of their association with the Brazil nut trees, suggesting further long-term studies for monitoring the production of the Brazil nut trees and consolidating their categorization; and,

- Brazil nut trees form very diverse forests, which reinforces the importance of Brazil nut trees and nuts collectors in maintaining Brazil nut trees, to generate income and conserve the diversity of tropical forests.

\section{ACKNOWLEDGMENTS}

To my advisors Dr. Nabor Pio and Dr. Kátia Emídio for all the guidance provided, time dedicated, patience, trust, friendship, and dedication.

To the Capes, for two years of scholarship that contributed to the conduction of the study.

To the Embrapa, for making available its facilities, equipment, vehicles available, in addition to the fruitful environment for debates with its researchers, employees and scholarship holders.

To the Institute of Sustainable Development of Agriculture and Forestry of Amazonas, for releasing me to carry out this work, for the logistical and financial support and for the partnership in the Project.

To the Chico Mendes Institute for Biodiversity and Conservation, the Environment Secretariat of the state of Amazonas for the studies in protected areas. 


\section{REFERENCES}

CONDÉ, T.M TONINI, H. Fitossociologia de uma Floresta Ombrófila Densa na Amazônia Setentrional de Roraima, Brasil. Acta Amazonica. Manaus, v. 43, n. 3, p. 247-260, set. 2013.

DIONISIO, L. F. S.; OSMAR-FILHO, S. B.; CRIVELLI, B. R. S.; GOMES, J. P.; OLIVEIRA, M. H. S.; CARVALHO, J. O. P. Importância fitossociológica de um fragmento de floresta ombrófila densa no estado de Roraima, Brasil. Revista Agro@mbiente, Roraima, v. 10, n. 3, p. 243-252, jul./set. 2016.

GUEDES, M. C.; TONINI, H.; WADT, L. H. O.; SILVA, K. E. Instalação e medição de parcelas permanentes para estudos com produtos florestais não madeireiros. In: WADT, L.H DE O.; SANTOS, L. M. H; BENTES, M. $P$ de M.; OLIVEIRA. Produtos florestais não madeireiros: guia metodológico da Rede Kamukaia. Embrapa, Brasília, DF: VBV. (Ed.), 2017.p. 13 - 32.

KNIGHT, D. H. A phytosociological analysis of species-rich tropical forest on Barro Colorado Island, Panama. Ecological Monographs, Amsterdã, 45:259-28, 1975.

MAGURRAN, A.E. Ecological Diversity and Its Measurement. Princeton University Press, Princeton, N.Jx, , p.179, nov.1988.

PAIVA, P. M; GUEDES, M. C; FUNI, C. Brazil nut conservation through shifting cultivation.For Ecol Management., Reino Unido, 261: PAIVA 508-514, feb. 2011.

PEREIRA, L. A.; PINTO SOBRINHO, F. de A.; COSTA NETO, S. V. da. Florística e estrutura de uma mata de terra firme na Reserva de Desenvolvimento Sustentável Rio Iratapuru, Amapá, Amazônia Oriental, Brasil. Floresta, Curitiba, v. 41, n. 1, p. 113-122, jan./mar.2011.

SANTOS, R. O dos; LIMA, R. C.; LIMA, R. B.; APARÍCIO, P. da S.; ABREU, J. C de. Florística e estrutura de uma comunidade arbórea na floresta estadual do Amapá, Amazônia Oriental, Brasil. Nativa, Sinop, v. 5, p.529539, dec. 2017.

SCOLES, R \& GRIBEL, R.Human Influence on the Regeneration of the Brazil Nut Tree (Bertholletia excelsa Bonpl.,Lecythidaceae) at Capan Grande Lake, Manicoré, Amazonas, Brazil. Human Ecology, Reino Unido, 39:455-464, aug. 2011.

SILVA, K. E.; MARTINS, S. V.; RIBEIRO, C. A. A. S.; SANTOS, C. P. A.; MATOS, F. D. A.; AMARAL, I. L. Floristic composition and similarity of 15 hectares in Central Amazon, Brazil. Revista de Biologia Tropical, Costa Rica, v.59, n.4, p:1927-1938, dec. 2011.

SILVA, K. E.; MARTINS, S. V.; RIBEIRO, C.A.A.S.; SANTOS, N.T.; AZEVEDO, C.P.Structure of 15 hectares permanent plots of terra firme dense forest in Central Amazon. Revista Árvore, Viçosa, v. 40, n. 4, p. 603-615, jul./aug. 2016.

SILVA, K.E; MATOS, F.D.A.; WADT, L.H.O.; GUEDES, M.C. Instalação de parcelas circulares para caracterização da vegetação associada a espécies arbóreas tropicais. In: WADT, L. H DE O.; SANTOS, L. M. H; BENTES, M. P. de M.; OLIVEIRA. Produtos florestais não madeireiros: guia metodológico da Rede Kamukaia. Embrapa, Brasília, DF: VBV. (ED.), 2017.p. 33 - 40.

TONINI, H.; PEDROZO, C.A. Variações anuais na produção de frutos e sementes de Castanheira-do-brasil (Bertholletia excelsa Bonpl. Lecythidaceae) em Florestas nativas de Roraima. Revista Árvore. Viçosa-MG, v.38, n.1, p.133-144, feb. 2014. 